\title{
TREATMENT OF TEXT IN VOCAL WORKS BY BOSNIAN AND HERZEGOVINIAN COMPOSERS
}

\section{AMRA BOSNIĆ}

\begin{abstract}
The paper discusses the half-century of composition in Bosnia and Herzegovina throughout the prism of musical setting to text phenomenon in vocal forms. In its focus are the solo song Pjesma u zoru by Milan Prebanda, Otvori u noć vrata by Vlado Milošević, Sappho by Nada Ludvig Pečar and The impact of the analogue synthesizer by Dino Rešidbegović. Analysis of the relationship between text and music in these works points out to the compositionaltechnical manner characteristic for these composers, generally marked by: Milošević consistently holds on to a text quantitative and qualitative characteristics, Prebanda raises melody above all the expressive characteristics, Ludvig Pečar holds to neoclassicist formal patterns, while Rešidbegović partly disposes the authority of vocal expressiveness to an interpretant.
\end{abstract}

Keywords: musical setting to text; Bosnian-Herzegovinian composers; compositional technique.

\section{Introduction}

The following paper originated from the considerations of recently revived systematic musicological research into the phenomenon of composing in Bosnia and Herzegovina (Bosnić, 2016). Although composing in Bosnia and Herzegovina is marked by elements of discontinuity, among other things, and the impossibility of creating the necessary conditions for normal (continuous) development (Čavlović, 1998, 57), one of the conclusions of the described, as well as other studies conducted on the same topic, was the continuity achieved in the composing style and genre link between individual poetics of different generations of composers; thus, in $\mathrm{BiH}$ composing, we find phenomena such as symphonism in the oeuvres of Miroslav Špiler (1906-1982), Vlado Milošević (1901-1990), Avdo Smailović (1917-1984), Vojin Komadina (1933-1997), Josip Magdić (1937), and Anđelka Bego Šimunić (1941) (Bosnić, 2010); folklore-marked oeuvres in all stages of composing, from harmonisations and arrangements to creations in the spirit of folklore and its polystylistic usability, or particularly prominent Neoclassicist style expression present until this day (Čavlović, 2011, 44; Hukić, 2012). This paper, however, focuses on a phenomenon that suggests developmental tendencies in the composing 
technique continuity in creation in $\mathrm{BiH}$ - vocal-instrumental genre of solo song, viewed from the angle of empirical-normative level of theoretical dealing with this issue. In other words, the paper is aimed at recognizing norms and laws of composing behavior/practice in the given genre, as one of historical facts that mark composing in Bosnia and Herzegovina, and also at singling out formal determinants that could suggest the development line in $\mathrm{BiH}$ composing.

The paper will focus on solo songs by four composers: Milan Prebanda (1907-1979), Vlado Milošević, Nada Ludvig Pečar (1929-2008) and Dino Rešidbegović (1975), in whose oeuvres the formal and structural characteristics ${ }^{1}$ of solo song are crystallized as the characteristics of the composer's individual style. Therefore, the paper focuses on meanings that these determinants represented as formal models for solo song - have in the listed oeuvres, by means of penetrating into the structure of the composer's relationship toward content and form as the essential issue of artistic creation, and, though indirectly, by reconstructing the chronology of these phenomena as a sign of developmental dynamics of a society's composing.

In retrospect, $\mathrm{BiH}$ composing began to develop more intensively with the arrival of Austro-Hungarian administration in the late $19^{\text {th }}$ century. After this preparatory stage of composers who arrived in $\mathrm{BiH}$ mostly from the neighbouring countries, the first aesthetically relevant manuscripts were provided by composers Milan Prebanda and Vlado Milošević, who made a transition toward the composing practice focused on the material with folklore spirit molded into elaborate formal solutions, which are here discussed as Models 1 and 2, respectively. These composers' interest in folklore is a belated response to the aesthetics of Romanticism national schools, practiced in less developed European societies in the $20^{\text {th }}$ century as well. When the second and third generation of composers matured, one could observe composers' interest in templates by $\mathrm{BiH}$ and other poets on universal topics, and gradual transition to the universal musical material - all of which is particularly prominent in song cycles by Nada Ludvig Pečar, as Model 3. The fourth generation experiences the vocal medium as equal to the instrumental one, expanding their interest in sound expanse offered by their symbiosis. Therefore, the sample of compositions by Dino Rešidbegović will be provided as Model 4.

1 Besides the harmonic makeup level, the solo song analysis will particularly focus on the segment of composing technique which deals with the relationship between text and music, as the basic analysis of formal makeup of solo song, at two structural levels: at the level of musicalizing the phonetic layer of textual template, i.e. its quantitative and qualitative characteristics and their translation into music, and at the level of syntactic layer of textual template, i.e. merging and combining phrase and sentence structures of the text with specific laws of musical form. (Čavlović, 2014, 570) 


\section{Melody Predominance over Text as Model 1: Milan Prebanda}

Solo song by composer Milan Prebanda will be discussed in the paper as Model 1 , since he installed a specific genre of Bosnian and Herzegovinian solo song, together with Vlado Milošević. Indeed, these composers were the first who systematically began to use $\mathrm{BiH}$ folk archetypes in the construction of formal type of solo song, thereby creating specific and original expressions, though equally quite different by formal characteristics. Prebanda's syllable signifies the prevalence of melody over text, the dominance of melodic-harmonic expressive aspect which conceals folk archetypes of urban musical tradition (sevdalink $\left.a^{2}\right)$, and a specific relationship between the piano and vocal part which evokes characteristics of the parlor-style $\mathrm{BiH}$ music of the beginning of the century. Harmonic characteristics include the colorist role of harmony, Romanticist chord fund, non-tonic beginnings with particularly noticeable use of half-diminished seventh chord on the second degree in the first inversion, a ring of modality. Formally, varied strophicity prevails, with permanent tendency for repetition by intervening in the text by repeating stanzas. An additional reference to sevdalinka is achieved by adding exclamations. The thematic framework consists of love poetry by South Slavic poets Razija Handžić, Aleksa Šantić, Guido Tartalja, Antun Gustav Matoš and others, and templates from folk music.

In Prebanda's expression, all musical means of expression, primarily the shaping of melody relating to phonetic and syntactic features of textual template, serve to depict the atmosphere present in the sevdalinka form. In this sense, text is subordinated to music, and music is the essential carrier of expression. As an example, we take the solo song Azemina ${ }^{3}$ (1946), which musicalizes a text by Razija Handžić (1910-1994). This model represents a feature of the composer's practice in musicalizing a template, where the composer attaches the importance

2 "Sevdalinka is a form characteristic of urban environment of Bosnian and Herzegovina," Karača Beljak, 1997, 55. "Sevdalinka is a prominently soloist song with a well-developed melody, frequently enriched with exclamations and melodic ornaments, created as a result of interweaving of authentic traditional forms of musical expression of the people of this region and elements of Middle East music. Its important feature is improvisation, the level of which depends on the performer's ability and skill." (Fulanović Šošić, 1997, 61)

3 I. Umrla je jutros plava Azemina/Nečujno ko zumbul klonuo od sjaja,/Sa tihim osmjehom oko sljepoočnica,/Da l' posljednje misli, il' modrih odsjaja. II.Smjenjujuć' se stalno mirni, kruti ljudi/Zibali joj tijelo niz sokake strme/K'o tužni znamen djevojačke smrti/Ljeskala na suncu marama od srme. III. Zastala u hodu jedna žena stara/Ispod vela šapnu: "Jadna Azemina,/ Ne bilo joj teško na onome svijetu/Voljela je, kažu, jednog kaurina." (I. Blonde Azemina died this morning/Silently as a hyacinth drooping of splendor./With a silent smile around her temples,/Was it her last thought, or blue reflection. II. Silent, rigid people alternated all the time/Carried her body along steep alleys/Like a sad symbol of a girl's death/Her silver scarf glittered in the sun. III. An old woman stopped/ And whispered behind her veil: "Poor Azemina,/Let her rest in the other world/She loved, they say, a giaour") 
to the quantitative characteristics of the template, which is understood as the "distribution of long and short tones in a bar, which follows the distribution of long and short syllables in a word" (Čavlović, 2014, 570). Since this layer of musicalizing a textual template actually pertains to the rhythm musical structure, the next example (Figure 1) reveals that the composer attentively listens for these laws of the text, which is also visible in the next example of musical notation. The composer musicalizes the first line (Umrla je jutros) by a series of eighth notes and a quarter note in the end, due to the length of the second syllable of the word jutros. This pattern results in the distribution of short and long tones in the following lines/bars, though with some disproportions (such as the word Azemina ${ }^{4}$, where the last syllable is musicalized with a longer note than the previous ones). This disproportion between the word and music primarily results from the described consistent use of the "given" rhythmical pattern of the first line, as well as from the primacy of the melodic line expression over the text. Indeed, the lyrical quality of the melodic layer of Prebanda's Azemina rests upon the folk archetypes of sevdalinka, primarily presented with a developed melodic line, natural-major sonority, augmented second as a recognizable linear move, emphasis of subdominant area in the very beginning on the 6/5 chord of the second degree, characteristic of Prebanda.
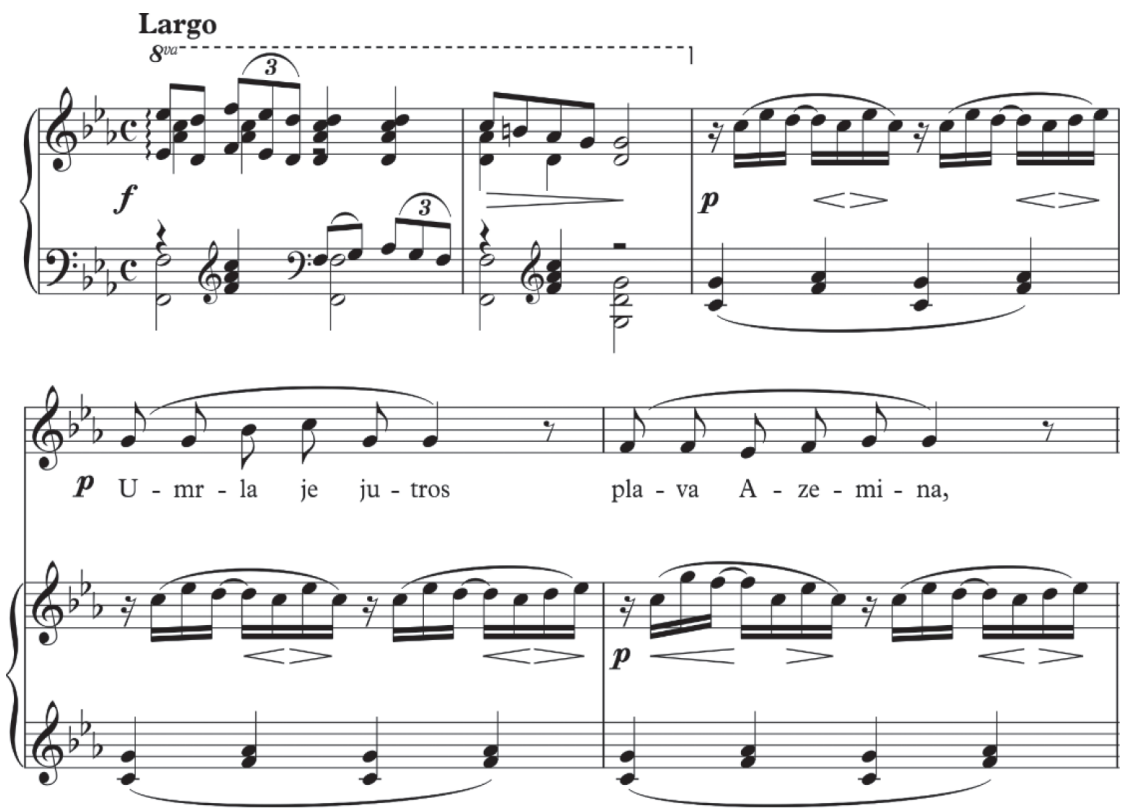

Figure 1. Prebanda. Azemina. b. 3.

${ }^{4}$ Long syllables are bolded, which will be done further in the text with stressed syllables in words. 
The analysis of qualitative layer as a text layer where the permanent distribution of stressed and unstressed syllables in a word gains prominence, as a sign of internal bar metrics achieved both with rhythmical and interval treatment of text and music (Čavlović, 2014, 507) shows that the consistent following of text's internal metrics is of secondary importance. In the discussed example, one can observe the distribution of heavy and light tones which musicalize the heavy and light syllables of the text, established in the first, single-bar motif, which continues across the template units (see Table 1). However, interval shifts lead to additional disturbance of the regularity of accentuation of textual template. The word umrla, which has a short falling stress, was musicalized first by static repetition of the same tone, and then by a rising leap of a third, which places stress on the unstressed syllable of the word (umrla). A similar procedure is used in the subsequent words, as well as in short words with only secondary semantic meaning. It means that the composer prioritizes laws of constructing musical dramaturgy, over the consistent listening for and conveying characteristics of text metrics into music, as is, for instance, practiced by Vlado Milošević.

If we consider musicalization of the syntactic layer of the template, we will observe that the global structure of Prebanda's song is a repetitive-type threepart piece (Table 1) within varied strophicity, which is one of the features of his style. The basic microstructural unit is a line, musicalized using a single-bar motif, which is then repeated three times thus bringing up the atmosphere of balladic narrativity, staticity and, besides other elements of expression, one of lamentation and acceptance. Prebanda frequently intervenes with the texts he chooses, thus creating the basis for dramaturgical framework: in this case, he repeats a fragment of the second line in the last stanza, thus evoking the text semantics with almost madrigal-type portrayal of emphatic sorrow that death brings. 


\begin{tabular}{|c|c|c|c|c|c|c|}
\hline \multirow{2}{*}{\multicolumn{2}{|c|}{ Text }} & \multicolumn{5}{|c|}{ Music/Syntactic layer of textual template muzicalizing } \\
\hline & & \multicolumn{2}{|c|}{ Macrostructure } & Microstructure & $\begin{array}{l}\text { Motivic } \\
\text { construction } \\
\text { relationship }\end{array}$ & $\begin{array}{l}\text { Tonal } \\
\text { plan }\end{array}$ \\
\hline & & \multirow{2}{*}{\multicolumn{2}{|c|}{ Introduction }} & 11 & $a b$ & $\mathrm{C}$ minor \\
\hline & & & & 1 & figure $2 \mathrm{X}$ & \\
\hline \multirow[t]{4}{*}{ I stanza } & I verse & \multirow[t]{4}{*}{ A } & \multirow[t]{2}{*}{ I section } & 11 & b1 b2 & \\
\hline & II verse & & & 11 & b3 b4 & \\
\hline & III verse & & \multirow[t]{2}{*}{ II section } & $0,5 \quad 0,5$ & a4 a5 & \\
\hline & IV verse & & & 11 & a6 a7 & \\
\hline \multirow[t]{4}{*}{ II stanza } & I verse & \multirow[t]{4}{*}{ B } & \multirow[t]{2}{*}{ I section } & 11 & $a b$ & \\
\hline & II verse & & & 11 & a b5 & \\
\hline & III verse & & \multirow[t]{2}{*}{ II section } & 2 & a8 & \\
\hline & IV verse & & & 11 & a9 a10 & \\
\hline & & \multicolumn{2}{|c|}{ passage } & 1 & Figure $2 \mathrm{X}$ & \\
\hline \multirow{6}{*}{$\begin{array}{l}\text { III } \\
\text { stanza }\end{array}$} & I verse & \multirow[t]{6}{*}{ a } & \multirow[t]{2}{*}{ I section } & 11 & b1 b2 & \\
\hline & II verse & & & 11 & b3 b4 & \\
\hline & III verse & & \multirow{4}{*}{$\begin{array}{l}\text { I section } \\
\text { (var.) }\end{array}$} & 11 & b6 b7 & \\
\hline & IV verse & & & 11 & b3 b4 & \\
\hline & II verse/frag. & & & 1 & b6 & \\
\hline & II verse/frag. & & & 1 & b8 & \\
\hline & & \multicolumn{2}{|c|}{ Coda } & 3 & figure $6 \mathrm{X}$ & \\
\hline
\end{tabular}

Table 1. Prebanda. Azemina. Formal-structural scheme of the syntactic layer of textual template muzicalizing 


\section{Melody of the Speech as Model 2: Vlado Milošević}

The next model is the speech melody used by Vlado Milošević, in whose oeuvre the solo song plays a prominent role (Čavlović, 2001). Style characteristics of his vocal works cover the following range: diverse topics, mostly by South Slavic poets: Mandić, Cesarić, Raičković, Humo, Risojević, Nastić, etc. His creative credo is folk music, although he achieves the best artistic results by combining archetypes of rural folk music of Bosnia and Herzegovina in melodic constructions: narrow interval shifts $(\mathrm{m} 2, \mathrm{u} 4)$, unstable scale degrees, diverse, frequently punctuated rhythm. Essentially, it results in a non-singable, recitative melody, hard to remember and less receptive. His harmonic fund is late-Romanticist with elements of Impressionism; harsh verticality is a product of autonomous, expressive lines, which results in harmonic instability. Formally, given the variation as the basic constructing procedure, his solo songs are marked by a through-composed form or, less frequently, varied strophicity without repetition.

With respect to text treatment, it should be noted that Milošević listened to the speech of his birth region, Bosanska Krajina, i.e. Zmijanje, and found it challenging to look for modes of consistent translation of speech layers into music. Although he never developed this intention to the level of theory, his instrumental themes interestingly emanate the melody structure that owes its origin to speech characteristics that the composer observed in a common man's speech which, to an extent, fits into the folk music archetypes of minor-second shifts, narrow ambitus and punctuated rhythm (Čavlović, 2001), although in this particular example it is read from the piano, rather than vocal section.

On the example of solo song Otvori u noć vrata (Open the door in the night $)^{5}$ from the cycle Deset pjesama na stihove Stevana Raičkovića (Ten songs on the Stevan Raičković's verses) (1961/62), we observe that the composer consistently follows both quantitative and qualitative characteristics of the word: at the quantitative level, the composer patiently listens to the rhythm of speech, which causes a variety of combinations of note values which rhythmicize individual words (or in combination with words of secondary semantic meaning).

5 I. Otvori u noć vrata neka se skloni drveće/Neka u prazne vaze uđe iz tame cveće. II. Otvori u noć vrata na brdu neko čeka/Da kaže bolne reči u živi sluh čoveka. III. Otvori u noć vrata i zidove polomi/Gorki svet jedan iz tame čeka da se udomi. (I. Open the door in the night/Let the trees fall/Let the flowers enter into the empty vases from the darkness. II. Open the door in the night/There is someone waiting on the hill/To say painful words in the living man's hearing. III. Open the door in the night and break the walls/A single bitter world is waiting to get home from the darkness.) 


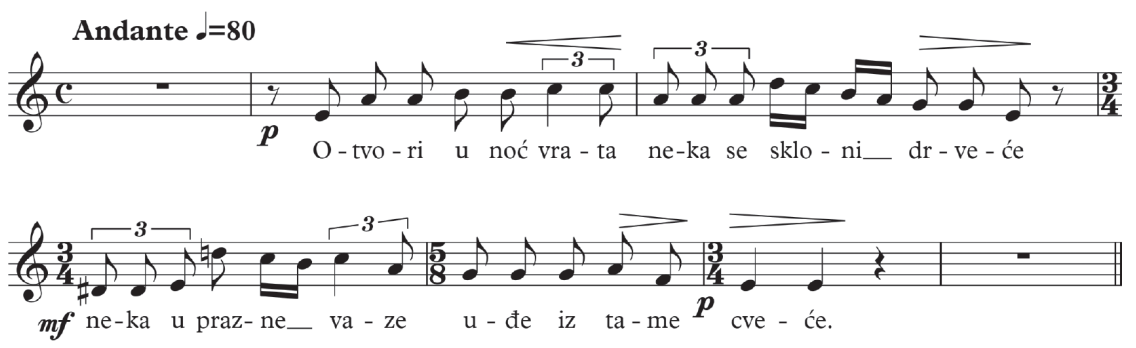

Figure 2. Milošević. Otvori u noć vrata. b. 3.

The consistent adherence to the template's quantitative and qualitative characteristics results in as many as ten time shifts in the relatively small musical space of the song. Besides, interval characteristics are as follows: rising stresses are musicalized with rising motion, or even a leap (otvori), while falling stresses are as a rule musicalized with falling melodic motion or a repeated tone of the same duration, depending on the position of the word in a bar, such as in the words drveće, bolne, prazne, etc. The resulting narrative melody structure fully corresponds to what was named the National Realism of Milošević's style expression (Čavlović, 2001).

With respect to the syntactic layer, one can observe the fragmentariness of micro-structural formation, which emerges as a result of variant development from the basic frontal motif of the song. The frontal motif musicalizes part of the first line (Otvori u noć vrata), and in the continuation of the stanza it variantly develops into template units, the melo-rhythm structure which depends on text characteristics. We observe that only the described unit is repeated in the threestanza textual template, which confirms that in Vlado Milošević's solo song all structure elements depend on the text. The harmonic structure of the song fully relies on a-minor; however, the use of a single key is sporadically disturbed by straying into the dominant area of e-minor, with a Phrygian ring, which is a clear reference to $\mathrm{BiH}$ folk music, with avoidance of determining sonority with empty fifth harmonies formed between the vocal and piano section. The following table suggests the varied strophicity. 


\begin{tabular}{|c|c|c|c|c|}
\hline \multicolumn{2}{|l|}{ Text } & \multicolumn{3}{|c|}{ Music/Syntactic layer of textual template muzicalizing } \\
\hline Stanza & Verse & Macrostructure & Microstructure & Tonal plan \\
\hline & & Uvod & 1 & A minor \\
\hline \multirow[t]{2}{*}{ I } & I & \multirow[t]{2}{*}{ a } & 11 & \\
\hline & II & & 3 & (E minor) \\
\hline & & passage & 1 & \\
\hline \multirow[t]{2}{*}{ II } & I & \multirow[t]{2}{*}{ a1 } & 11 & A minor \\
\hline & II & & 2 & \\
\hline \multirow[t]{2}{*}{ III } & I & \multirow[t]{2}{*}{$\mathrm{a} 2$} & 11 & \\
\hline & II & & 2 & \\
\hline
\end{tabular}

Table 2. Milošević. Otvori u noć vrata. Formal scheme of the syntactic layer of textual template muzicalizing

\section{Musical Form Authority as Model 3: Nada Ludvig Pečar}

The next model presents Nada Ludvig Pečar, a composer who remained loyal to a single expression style - Neoclassicism, which is the foundation of her relationship to material and form. Reaching for the poetry by Ancient Greek poet Sappho in the song cycles Sappho (1973) and Kumi, whose sensual poetic style enchanted with its melodiousness, dealt with topics such as love, longing, passion, attraction and often, in her poems, tackling the issue of woman - to which she was ideologically devoted, provides her composing procedure with the gender identity. Sappho's poems selected by Ludvig Pečar do not speak of the woman's explicit love for a man, but rather about the woman's intimate world in her loneliness and longing (Ponoć/Midnight), pain (Djevojčin jad/Girl's misery), the mother's love for the child (Moje dijete/My child), uniqueness of her being (Pjesma o djevojci/A Song about a Girl), or fascination with music and nature (Lira, Proljeće/Lyre, Spring). Since the universal material is systematically implemented throughout her oeuvre, this paper views the model of Nada Ludvig Pečar's solo song from this angle as well, with unavoidable discussion of composing postulates applied in the actual example.

Characteristics of style of her vocal pieces are reduced to melodies with the ambitus of tonic pentachord or hexachord core, sometimes expanded exclusively with the leading note as a switch to the first degree. The harmony rests upon the major-minor system, frequently colored with modality ring. The texture is homophonous, bi-level and transparent, with the voice part as the leading melodic part, and with the presence of diverse melodic instruments and exotic percussions, suggesting specific atmospheres of medieval secular songs and 
dances: pastorals, chansons, ballads. The form is clearly dissectable and well laid out, with patterns of varied strophic song or song with a refrain.

Musicalization of textual template in the song Proljeće (Spring) ${ }^{6}$, the last song in Sappho - a cycle of songs for mezzo soprano, flute, clarinet, viola, piano and percussions, implies the full authority of the musical layer, which is not conditioned by the phonetic layer of poetic template. The composing technique deals with achieving an expression that is fully left to the structural and melodicharmonic expressiveness. Deviation from the consistent musicalization of textual template and its phonetic characteristics make the text, in certain examples, almost incomprehensible. Its semantic meaning is thus completely abstracted and replaced with the meaning that this layer of musical form has, and which serves to achieve a specific atmosphere of informal medieval secular music-making of travelling musicians. The introduction (Figure 3) presents the basic melodic-harmonic material, organized in G Myxolydian Mode, in its hypo variant. The basic pattern consists of the first four-bar sequence, which presents a latent melodic line (d-e-d-c) within the harmonic progression: I - II - I - VII, on the pedal tone of the dominant. The further sequence is based on permuting the former one, with the addition of variant III degree, VI, IV, and major dominant, according to the following scheme: I - II - I - VII - I - II I - IIIv - I - IIIv - I - II - I - VII - VI - VII - IV - V - VI - V. The tendency of graduality in melodic stringing is evident, and it is frequently made up of a row of three switching harmonies (e.g. I - II - I - VII - I, VII - VI - VII, V VI - V), and return to the I degree in the first part of introduction. The effect of a round dance, which is achieved by this procedure and which forms the basis for the underlying mood of the song, underlines the three-part quality of the bar with stress and makeup; indeed, throughout the song the piano part breaks down the previously mentioned quintal chords in the form of figure - empty fifth on the first beat, third-based supplement on the second beat, and pedal tone on the third one. Although the supplement to the chord with the "missing" third comes in the left hand, and despite the lowest fifth suggesting a 6/4 chord, it is the sonority of empty fifths that adds to the expression some archaic quality, simplifies the musical flow and provides it with certain lightness and freedom. The simplicity of the accompaniment layer, soon supplemented by percussions (castanets, small drum) will ensure the movable lying tone for the basic melody which is anticipatively presented in the introduction in the imitation of flute and clarinet. This four-bar sequence is shaped by two two-bar motifs: the first is distinctive by the rising fifth chord of first degree and then remaining on the tone of subdominant, while the second is its inverted variant ending on the VII

6 Osjećam da je proljeće blizu/Brzo dones'te slatko vino/Nek’se pehari pune. (I feel the spring is near/Quickly bring the sweet wine/Let some cups full.) 
degree. This melodic line will be taken over by the vocal part. With its arc-like line, the melody joins the other elements of expression in portraying the underlying atmosphere of spring light-heartedness, dance and song symbolizing it.

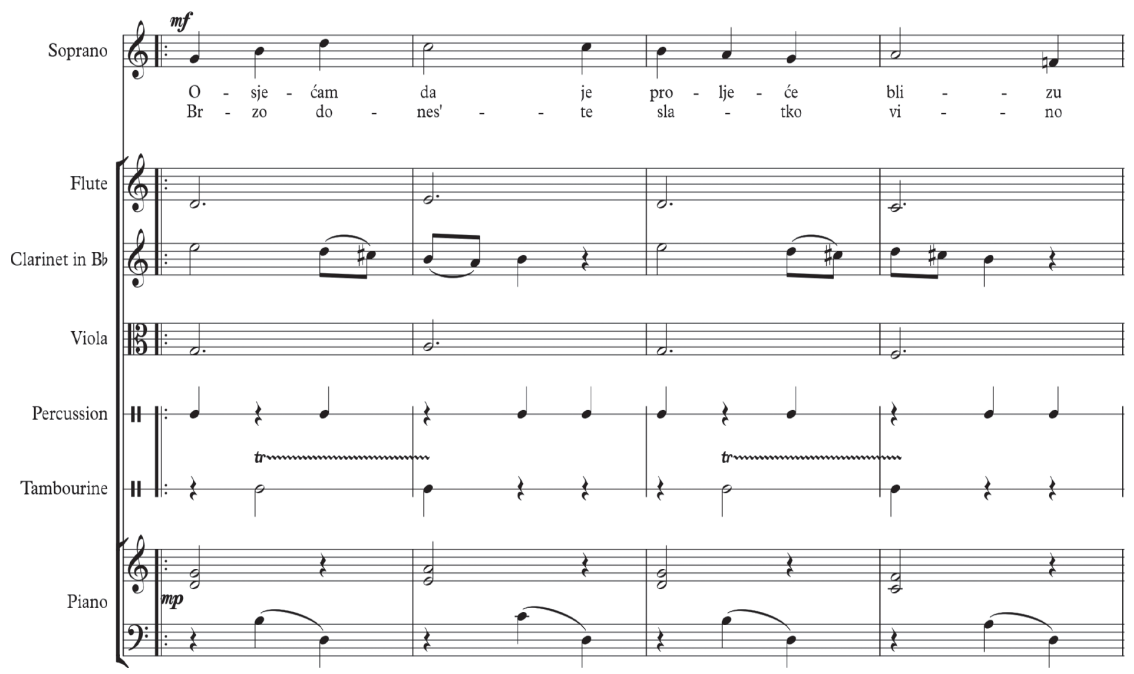

Figure 3. Ludvig-Pečar. Sappho: Proljeće. b. 20.

Thus, the syntactic layer of template musicalization shapes the material in the typically classic way - according to the principle of two-bar phrases that relate to each other as correspondence. In order to achieve this, the composer sometimes even intervenes with the text and changes it to achieve symmetry; sometimes, on the other hand, she deviated from this pattern and extends the last tone of the melodic phrase (the first three-bar sequence in stanzas).

\begin{tabular}{|c|c|c|c|c|c|}
\hline Part & Introduction & A & $\mathrm{A} 1$ & Coda & \multirow{4}{*}{$\begin{array}{l}\text { G } \\
\text { mixolid. }\end{array}$} \\
\hline Bars & 1010 & $10 \quad 10$ & 1010 & $\begin{array}{ll}9 & 11\end{array}$ & \\
\hline $\begin{array}{l}\text { Motiv } \\
\text { structure }\end{array}$ & 5522224 & 222312242 & same as $\mathrm{A}$ & 2222 fig. & \\
\hline $\begin{array}{l}\text { Motiv } \\
\text { construction } \\
\text { relationship }\end{array}$ & fig. a a 1 a 2 a 3 & a a 1 a 2 a 4 a a 1 a5 & same as $\mathrm{A}$ & imitative & \\
\hline
\end{tabular}

Table 3. Sappho, Proljeće. Formal scheme of syntactic layer of the textual template muzicalizing 


\section{“Mechanized” expression as Model 4: Dino Rešidbegović}

Solo song is interesting for the fourth generation of composers as well, among others for Dino Rešidbegović, who is truly interested in the solo song as a form, though bringing fresh ideas in terms of text treatment. Characteristics of style in his composing work so far include topics of templates originating in popculture, such as cycle of Jim Morrison's poems (poem cycle Underwaterfall), and curiosities also include the treatment of non-poetic text. In his continuous, individual quest for a new, original expression, Rešidbegović belongs to the generation of $\mathrm{BiH}$ composers who join contemporary artistic trends of Europe and the world. He is interested in musical experiment focused on the performer as a co-creator of a piece of music: he questions the relationship between the composer, as the initiator of the creative process and the performer, who shows his/her own creativity. His vocal works deal with the phenomenon of sound obtained using expanded vocal techniques with instrumental accompaniment.

Such an example is found in the piece The impact of the analog synthesizer (2015) for mezzo soprano, flute, violoncello, accordion and piano. The composer uses a non-poetic text - more accurately, he uses a quote from the preface to the book Analog Synthesizer (Jenkins, 2007, 12)7. The text is presented by both vocal and instrumental layer, though treated in different ways. Indeed, the first, vocal, mezzo soprano layer presents a distinctive recitative, i.e. speech-like singing with unfixed pitch. In line with his composing philosophy, the composer leaves the pitch up to the performer, while he prescribes the rhythm, in the way that he rhythmicizes two-syllable words with a figure of two sixteenth notes, foursyllable words with a figure of four sixteenth notes, and three-syllable words with a figure of triplet. In doing so, he separates individual words in the phrase using rests suggesting a specific, "mechanized", "robotic", "coded" expression. Thus, the quantitative characteristics of the template are given while the qualitative ones, in their part pertaining to stress melodic characteristics are improvised by the performer. (Figure 4)

7 "The impact of the analog synthesizer was more or less instant. Used as much to imitate conventionla instruments as to generate new sounds, within only a few years it was raising questions from musicians' unions about possible unemploxemnet caused amongst their members, Within ten years it was a staple element of all types and experimental music, ant it certainly was replacing orchestral musicians in many aplications." 


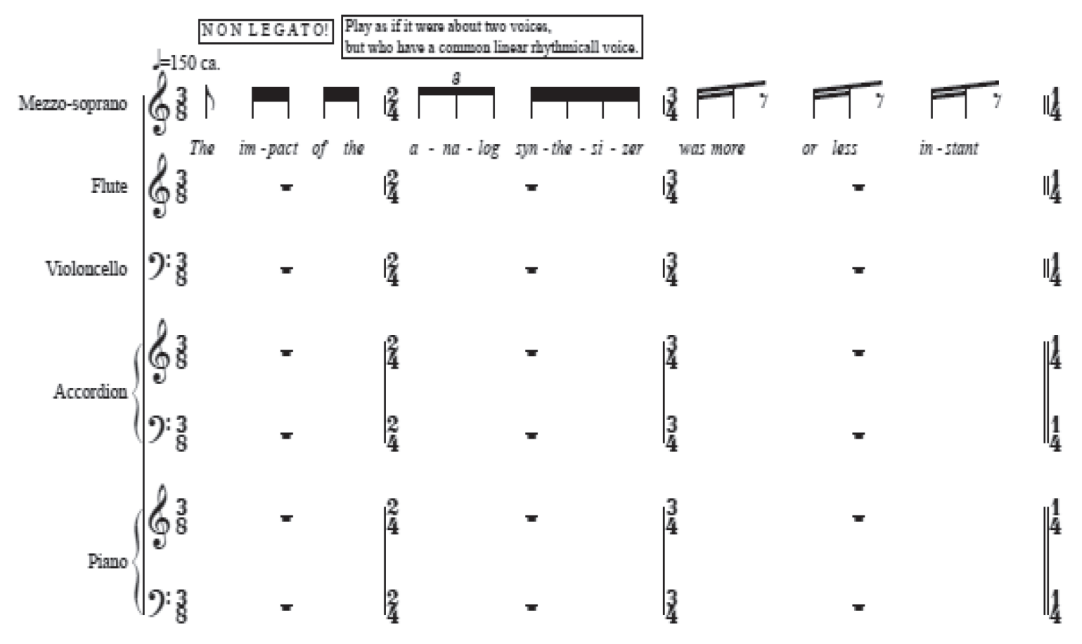

Figure 4. Rešidbegović. The impact of the analog synthesizer. b. 1.

The second, instrumental layer, which counterpoints the first one, consists of instruments which, in a complex polyphonic texture present a text coded in Morse alphabet: each letter of the text coded as a symbol of Morse alphabet is transcribed into a rhythm pattern, according to the legend provided in Figure 5.

\section{MORSE CODE TRANSLATED}
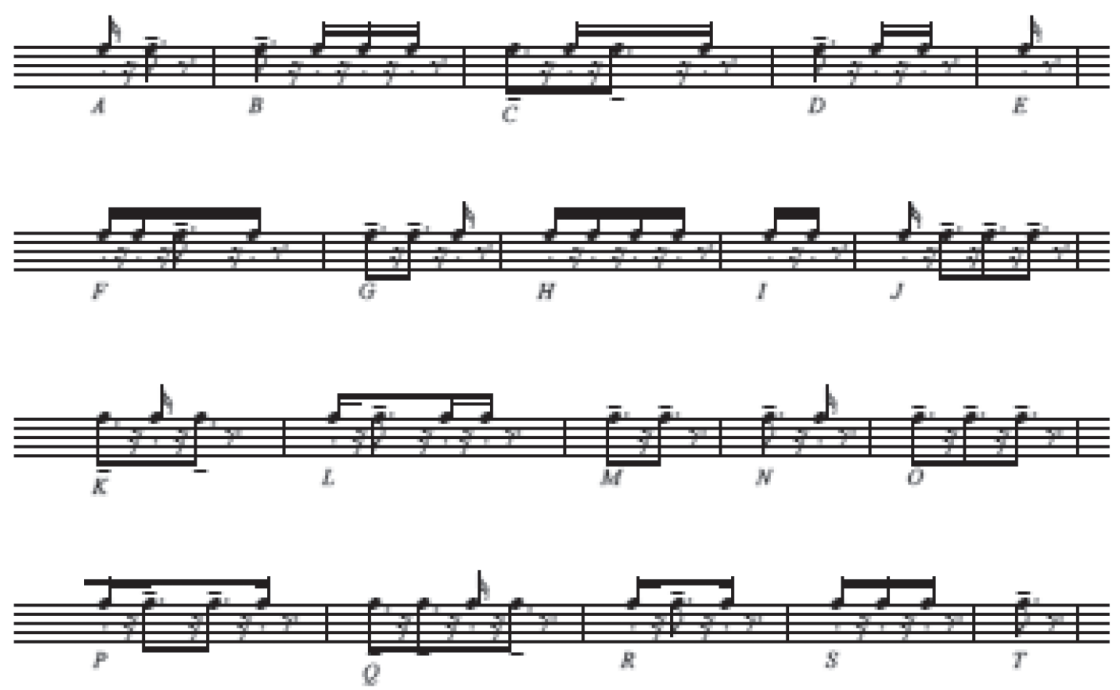

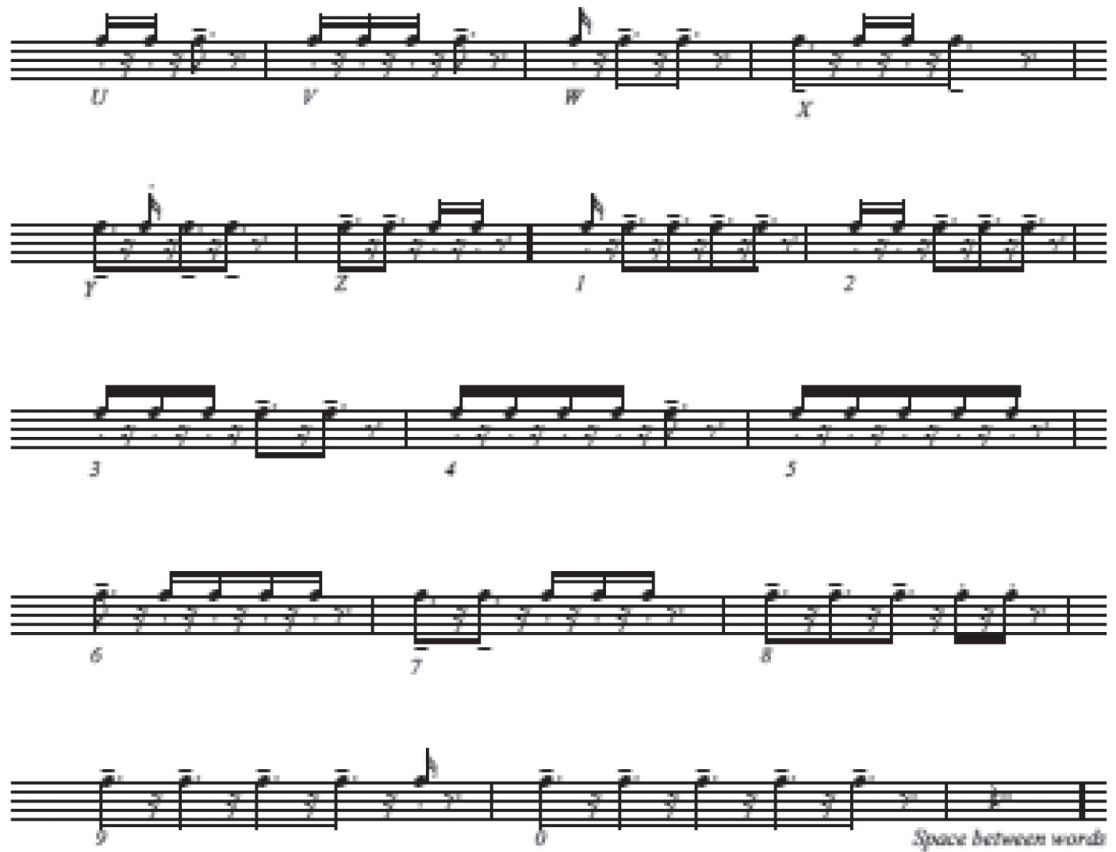

Figure 5. Rešidbegović. The impact of the analog synthesizer. Morse-code translated into rhythm patterns.

\section{Conclusion}

The described four models, specific for their composing-technique and style characteristics, provide a paradigm that suggests their meanings which are here read in at least two different ways. The first meaning is the immanently artistic meaning. Solo song as a formal type with a defining parameter of the relationship between the vocal and instrumental part offers the possibility of such a perception since it is one of the few formal types that composers of Bosnia and Herzegovina are continuously interested in. Therefore, by tracking the described formal models, one can observe, in Prebanda's model, a Romanticist treatment of musical material and dealing with the form in the manner of German Lied, situated in the historically, socially and culturally precious dawn of composing in Bosnia and Herzegovina, though anachronous compared to Western European model of art music. A similar aesthetic fact also marks Milošević's model of solo song, though a departure from such a Romanticist way of composer reasoning is provided by the form as a result of dealing with non-composing components 
of conditioned material. These two composers therefore represent the historical starting point from which composing in Bosnia and Herzegovina would begin its intensive development and emerge in other relevant works, such as those by Avdo Smailović, Vojin Komadina or Josip Magdić. Departure from folk music as the starting point in creation, which kept Bosnian and Herzegovinian composers in anachronous frameworks, as we saw in the described models, would bring about the treatment of universal material, here paradigmatically presented with the model of Ludvig Pečar, though with Neoclassicistically conceived references to medieval expressive context. The synchronous merging into the European artistic milieu would thus emerge only in recent composers' consideration of challenges of source and giving life to new artistic ideas. Thus articulated meaning of the composing-technique layer of the model presented in this paper therefore also implies the meaning that we can read as developmental tendencies in composing of a society, particularly of a society that has built its own concept of composing with different historical dynamics. Still, it must be remembered that such a meaning is conditioned by the perception of individuals who understand composing as a phenomenon of Western European artistic setting.

\section{References}

Bosnić, A., 2010. Simfonijska muzika u Bosni i Hercegovini. Master Thesis. Muzička akademija Univerziteta u Sarajevu.

Bosnić, A., 2016. Kompozitorstvo u Bosni i Hercegovini. Ph. D. Muzička akademija Univerziteta u Sarajevu.

Čavlović, I., 1999. Neki problemi muzike u Bosni i Hercegovini. In: I. Čavlović, ed. Collection of papers of the 1st International Symposium "Music in society". Sarajevo: Muzikološko društvo. 53-61.

Čavlović, I., 2001. Vlado Milošević - kompozitor. Sarajevo: Muzikološko društvo $\mathrm{FBiH}$.

Čavlović, I., 2011. Kompozitorstvo u Bosni i Hercegovini. Muzika, XV/2 (38), 36-54.

Čavlović, I., 2014. Muzički oblici i stilovi. Analiza muzičkog djela. Sarajevo: Muzička akademija.

Fulanović Šošić, M., 1997. Svatovske pjesme kao primjer zajedničke kulturne tradicije naroda u Bosni i Hercegovini. Muzika I/1 (1), 61-69.

Hukić, N., 2012. Neoklasicistička harmonija i njen utjecaj na bosanskohercegovačke autore. Master Thesis. Muzička akademija Univerziteta u Sarajevu.

Hukić, N., 2016. Harmonijski jezik u koncertima bosanskohercegovačkih kompozitora. Ph. D. Muzička akademija Univerziteta u Sarajevu.

Jenkins, M., 2007. Analog Synthesizers. Understanding, performing, buying. Oxford: Elsevier. 
Ludvig Pečar, N., 1973?. Sappho. [score] Sarajevo: Udruženje kompozitora Bosne i Hercegovine.

Milošević, V., 1964. Ciklus pjesama na stihove Stevana Raičkovića. [score] Sarajevo: Udruženje kompozitora Bosne i Hercegovine.

Prebanda, M., 1949. Pjesme za jedan glas i klavir. [score] Sarajevo: Svjetlost.

Rešidbegović, D., 2015. The Impact of the Analog Synthesyzer. [manuscript] Sarajevo: Personal Archiv of Dino Rešidbegović. 